\title{
CONSTRUCCIÓN DE TABLAS DE VIDA DINÁMICAS PARA UNO O DOS SEXOS / CONSTRUCTION OF UNISEX OR SEX-DISTINCT DYNAMIC LIFE TABLES
}

\author{
Ewa Dylewska ${ }^{1}$ \\ ewa@dylewska.com \\ Metlife Amplico, Polska \\ Ma Purificación Galindo Villardón² \\ p.galindo@usal.es \\ Universidad de Salamanca
}

\section{Resumen}

Mientras que las tablas de vida tradicionales describen la mortalidad actual en un determinado periodo de tiempo, las tablas de vida dinámicas permiten una proyección de mortalidad futura. Además de la edad y el sexo, las tablas de vida dinámicas tienen también una tercera dimensión, que es el tiempo. Por lo tanto, permiten observar cambios en la mortalidad que resultan no solamente de cambios en la edad sino también de cambios que aparecen a lo largo del tiempo. Esto se refiere sobre todo a la tendencia de disminución de riesgo de mortalidad. Las tablas de vida dinámicas son, por lo tanto, muy útiles en la construcción de seguros de vida de larga duración y planes de pensiones. También pueden ser aplicadas en la construcción de tablas unisex (relacionado con el dictamen C-236/09 - Test -Achats).

El objetivo del estudio es comprobar la diferencia en la esperanza de vida a la edad $x$ en España calculada utilizando las tablas de vida estáticas (tradicionales) y dinámicas, para uno 0 ambos sexos. Este fin se realiza aplicando el modelo de Lee-Carter para pronosticar la mortalidad futura.

Palabras clave: Tablas de vida dinámicas; Modelo de Lee-Carter; Proyección de mortalidad.

\section{Abstract}

Traditional life tables describe a level of mortality at one and defined period of time whereas dynamic life tables allow for projection of future mortality. Apart from age and gender, dynamic life tables also have a third dimension, which is time. In that way, it is possible to observe changes of mortality over the years. This is especially reflected in a mortality reduction trend. Dynamic life

1 Metlife Amplico, Polska.

2 Departamento de Estadística, Facultad de Medicina, Universidad de Salamanca, Campus de Miguel de Unamuno, c/ Alfonso X El Sabio, s/n, 37007-Salamanca. 
tables are therefore very useful in pricing long-term life contracts and especially in pricing annuities. Moreover, dynamic life tables can also be used in constructing unisex life tables (in relation with decision C-236/09 - Test-Achats).

The purpose of this paper is to demonstrate differences in life expectancy at age $x$ in Spain calculated by using static (traditional) and dynamic life tables, both unisex and sex-distinct. Mortality projection is done through the application of the Lee-Carter model.

Keywords: Dynamic life tables; Lee-Carter model; Mortality projection.

\section{INTRODUCCIÓN: IDEA DE TABLAS DE VIDA DINÁMICAS}

Las tablas de vida dinámicas representan las estimaciones del valor de la probabilidad de muerte correspondiente a la edad $x$ en el año $t\left(\hat{q}_{x t}\right)$ (Dylewska y Galindo, 2011).

Este tipo de tablas de vida se basan en unas tablas estáticas a las que se aplica una función de ajuste que representa el cambio en el riesgo de mortalidad a la edad $x$, que tiene lugar durante $t$ años. Las tablas de vida dinámicas asumen que la supervivencia de una cohorte depende del tiempo físico pues el requisito de estacionariedad, en su caso, no se verifica. En otras palabras, las tablas dinámicas se construyen con el objetivo de representar una proyección de la mortalidad de una cohorte, cuyo riesgo de mortalidad depende no solamente de la edad $(x)$ sino también del tiempo físico $(t)$.

Existen varios modelos que permiten calcular la disminución del riesgo de mortalidad año por año y de este modo construir tablas de vida dinámicas. Entre los modelos más utilizados en la práctica actuarial se encuentran el método de Factor de Reducción (Reduction Factor) propuesto por Continuous Mortality Investigation Committee (1999) y el Modelo de Lee-Carter (Lee y Carter, 1992), con modificaciones de numerosos autores.

\section{INTRODUCTION: THE IDEA OF DYNAMIC LIFE TABLES}

Dynamic life tables represent the estimation of the probability of death at age $x$ and time $t\left(\hat{q}_{x t}\right)$ (Dylewska and Galindo, 2011). This type of life tables are based on static (traditional) life tables and on a mathematical model which describes the change in mortality risk at age $x$, and which takes place over $t$ years. Dynamic life tables represent the biometric model of a population, as they assume the survival of a cohort also depends on time and assumptions regarding stationarity of the model cannot be satisfied. The main aim of constructing dynamic life tables is to represent a projection of the mortality of a cohort whose risk of death depends not only on age $(x)$ but also on time $(t)$.

There are various models which allow us to calculate the improvement in mortality year by year and therefore can be used to build dynamic life tables. The most popular and currently applied methods in actuarial practice are the Reduction Factor method proposed by the Continuous Mortality Investigation Committee (1999) and the Lee-Carter model (Lee and Carter, 1992) with some modifications proposed by various authors. Detailed review of methods and models currently applied was presented inter alia by Booth (2006). 
Una detallada revisión de los métodos y modelos aplicados en la actualidad para el ajuste de la mortalidad fue presentada, por ejemplo, por Booth (2006).

Una tabla dinámica tiene dos o más dimensiones, dependiendo del número de parámetros del modelo utilizados para su creación. El estudio de Debón, Martínez y Montes (2007) presenta las tablas dinámicas creadas con la aplicación de los modelos dependientes de edad y cohorte (age-cohort model), edad y periodo (age-period model), edad, periodo y cohorte (age-period-cohort model) o edad y deriva (age-drift model). Normalmente las filas de una tabla dinámica representan la edad $(x)$ y las columnas representan años consecutivos, o bien el número de años que han transcurrido desde el momento $0(t)$. Un esquema de la tabla de mortalidad dinámica se presenta a continuación:
A dynamic life table has two or more dimensions, depending on the number of parameters used in the model. In the study of Debón, Martínez and Montes (2007) different dynamic life tables are shown: based on age and cohort (agecohort model), age and period (ageperiod model), age, period and cohort (age-period-cohort model) or age and drift (age-drift model). Generally, across lines of the dynamic life table represent age $(x)$ and down columns represent consecutive years or number of years $(t)$ starting from a defined period 0 . A sample of a dynamic life table is provided below:

\section{Tabla 1. Esquema de tabla de mortalidad dinámica} Table 1. Sample of a dynamic life table

\begin{tabular}{|c|c|c|c|c|c|c|}
\hline $\mathbf{x} \mid \mathbf{t}$ & $\mathbf{0}$ & $\mathbf{1}$ & $\mathbf{2}$ & $\mathbf{3}$ & $\mathbf{. .}$ & $\mathbf{n}$ \\
\hline 0 & $\mathrm{q}_{0,0}$ & $\mathrm{q}_{0,1}$ & $\mathrm{q}_{0,2}$ & $\mathrm{q}_{0,3}$ & $\ldots$ & $\mathrm{q}_{0, \mathrm{n}}$ \\
\hline 1 & $\mathrm{q}_{1,0}$ & $\mathrm{q}_{1,1}$ & $\mathrm{q}_{1,2}$ & $\mathrm{q}_{1,3}$ & $\ldots$ & $\mathrm{q}_{1, \mathrm{n}}$ \\
\hline 2 & $\mathrm{q}_{2,0}$ & $\mathrm{q}_{2,1}$ & $\mathrm{q}_{2,2}$ & $\mathrm{q}_{2,3}$ & $\ldots$ & $\mathrm{q}_{2, \mathrm{n}}$ \\
\hline$\ldots$ & $\ldots$ & $\ldots$ & $\ldots$ & $\ldots$ & $\ldots$ & $\ldots$ \\
\hline 110 & $\mathrm{q}_{110,0}$ & $\mathrm{q}_{110,1}$ & $\mathrm{q}_{110,2}$ & $\mathrm{q}_{110,3}$ & $\ldots$ & $\mathrm{q}_{110, \mathrm{n}}$ \\
\hline
\end{tabular}

Cada diagonal de la matriz corresponde a una cohorte, es decir, a un grupo de individuos nacidos en el mismo año. La mortalidad a la misma edad de varios cohortes es distinta y normalmente disminuye a medida que aumenta el año de nacimiento. A veces ocurre que el cambio de mortalidad de unas cohortes o grupos de cohortes es muy distinto a otros. Este efecto se denomina el efecto de la cohorte (cohort effect).
Each diagonal of the matrix represent one cohort, which is a group of individuals born in the same year. Mortality at the same age of different cohorts is not the same and generally the lower it is, the older the cohort grows. It may occur that change of mortality of some cohorts or groups of cohorts varies a lot from one another. This effect is known as cohort effect. 
La elección de una columna de la matriz permite crear una tabla de vida estática pronosticada para el horizonte de $t$ años. Además, en la práctica actuarial puede resultar útil crear una tabla abreviada que recoja resultados para una sola cohorte (una diagonal de la tabla dinámica entera). Entonces, la tabla dinámica que describe la mortalidad de una cohorte a la cual pertenece un individuo de edad $x_{d}$, asumiendo una disminución de la mortalidad cada año $t$, tendrá la forma siguiente:
The selection of one column of the matrix allows us to create a static life table projected for $t$ years. Moreover, in some cases, in practice, it may be useful to create a table that contains results for one only cohort (one diagonal of the whole dynamic life table). In such a case, the dynamic life table describing mortality of one cohort to which an individual in age $x$ belongs, assuming mortality improvement each $t$ year, will be the following:

\section{Tabla 2. Esquema de tabla de mortalidad dinámica abreviada Table 2. Sample of an abbreviated dynamic life table}

\begin{tabular}{|c|c|}
\hline $\mathbf{X}$ & $\mathrm{q}_{\mathrm{x}, \mathrm{t}}$ \\
\hline$X_{d}$ & $\mathrm{q}_{\mathrm{xd}, 0}$ \\
\hline$X_{\mathrm{d}+1}$ & $\mathrm{q}_{\mathrm{xd}+1,1}$ \\
\hline$X_{\mathrm{d}+2}$ & $\mathrm{q}_{\mathrm{xd}+2,2}$ \\
\hline$\ldots$ & $\ldots$ \\
\hline 110 & $\mathrm{q}_{110,110-\mathrm{xd}}$ \\
\hline
\end{tabular}

\section{EL MODELO DE LEE-CARTER}

El modelo de predicción de la mortalidad llamado en la actualidad el "modelo de Lee-Carter" fue propuesto por Ronald D. Lee and Lawrence R. Carter en el año 1992 (Lee y Carter, 1992). El primer modelo fue ajustado para la población de Estados Unidos; los datos históricos consistían en ratios de mortalidad poblacional por edad para los años 1933-1987. Los autores no disponían de información detallada sobre la mortalidad a partir de 85 años de edad.

El objetivo del modelo de Lee-Carter es calcular el riesgo de mortalidad a la edad $x$, en el instante $t$, estimando previamente los parámetros de la siguiente función:

$$
m_{x, t}=e^{a_{x}+b_{x} k_{t}+\varepsilon_{x, t}} .
$$

\section{LEE-CARTER MODEL}

The model widely used at present for mortality improvement projection is the Lee-Carter model which was proposed in 1992 by Ronald D. Lee and Lawrence R. Carter (Lee and Carter, 1992). The first model was estimated for the population of the United States. The data consisted of historical population mortality rates focusing on age in years 1933-1987. Mortality rates for ages over 85 were not considered due to lack of reliable data.

The purpose of Lee-Carter model is to calculate the mortality risk at age $x$, in the moment $t$, estimating parameters in the following function:

$$
m_{x, t}=e^{a_{x}+b_{x} k_{t}+\varepsilon_{x, t}} .
$$


En el modelo propuesto, $k_{t}$ es un índice dependiente del tiempo $t$ que describe el nivel de mortalidad, para determinados coeficientes de $a_{x}$ y $b_{x}$. La observación de los valores de $k_{t}$ permite describir la tendencia de la mortalidad durante el periodo observado. Los valores del coeficiente $b_{x}$ permiten determinar la fuerza de disminución de la mortalidad para un cambio de $k_{t}$ :

$$
k_{t}\left(\frac{d \ln \left(m_{x, t}\right)}{d t}=b_{x} \frac{d k_{t}}{d t}\right)
$$

El coeficiente $a_{x}$ representa una media de valores de logaritmos naturales de $m_{x}$ para la misma edad $x$ y varios momentos $t$.

Los errores del modelo $\left(\varepsilon_{x, t}\right)$ siguen una distribución normal con media 0 y varianza $\sigma^{2}$ y reflejan los cambios de mortalidad que no están descritos por el modelo.

Con el fin de estimar los parámetros del modelo $\left(a_{x}, b_{x}, k_{t}\right)$ se aplica el método de descomposición de valores propios (single value decomposition). Para encontrar la solución única se requieren las siguientes condiciones:

$$
\begin{aligned}
& \sum_{i=0}^{\omega} b_{x}=1 \\
& \sum_{t=1}^{T} k_{t}=0
\end{aligned}
$$

Aplicando el método de mínimos cuadrados se busca el mínimo de la función:

$$
\begin{gathered}
\sum_{x=0}^{\omega} \sum_{i=1}^{T}\left(\ln \left(m_{x, t}\right)-a_{x}-b_{x} k_{t}-e_{t}\right)^{2} \rightarrow \\
\text { min. }
\end{gathered}
$$

Al estimar los parámetros, el modelo de Lee-Carter permite pronosticar la mortalidad futura. Con este fin se asume que los parámetros $a_{x}$ y $b_{x}$ son constantes y solamente $k_{t}$ se modifica con el tiempo. Lee y Carter, construyendo un modelo
In the proposed model, coefficient $k_{t}$ depends on time and describes level of mortality risk for defined coefficients $a_{x}$ and $b_{x}$. Observation of values of $k_{t}$ allows us to describe mortality evolution over the period under study. Values of the coefficient $b_{x}$ allow to measure mortality improvement for each change of $k_{t}$ :

$$
k_{t}\left(\frac{d \ln \left(m_{x, t}\right)}{d t}=b_{x} \frac{d k_{t}}{d t}\right)
$$

Coefficient $a_{x}$ represents an average of natural logarithms of $m_{x}$ for the same age $x$ and in the different $t$ moments.

Errors of the model $\left(\varepsilon_{\mathrm{x}, \mathrm{t}}\right)$ have a normal distribution with average value 0 and variance $\sigma^{2}$ and represent mortality changes which are not described by the model.

In order to estimate parameters of the model $\left(a_{x}, b_{x}, k_{t}\right)$ a single value decomposition method is applied. A unique solution of the problem requires the following conditions:

$$
\begin{aligned}
& \sum_{i=0}^{\omega} b_{x}=1 \\
& \sum_{t=1}^{T} k_{t}=0
\end{aligned}
$$

Applying the least squares method we search for the minimum in the following function:

$$
\begin{gathered}
\sum_{x=0}^{\omega} \sum_{i=1}^{T}\left(\ln \left(m_{x, t}\right)-a_{x}-b_{x} k_{t}-\right. \\
\left.e_{t}\right)^{2} \rightarrow \min .
\end{gathered}
$$

Having estimated parameters of the LeeCarter model, it is possible to project future mortality. For the purpose of projection it is assumed that parameters $a_{x}$ and $b_{x}$ are constant over time and only $k_{t}$ changes over the period in question. Lee and Carter, when estimating parameters of the model for the population 
para Estados Unidos, comprobaron que, en su caso, los valores de $k_{t}$ se pueden calcular mediante el modelo de camino aleatorio (single walk with drift). Sin embargo, para distintas series de datos históricos, pueden ser más adecuados otros modelos de series temporales (Lee y Carter, 1992).

Si la evolución del índice de mortalidad en cada momento $t\left(k_{t}\right)$ sigue un camino aleatorio (single walk with drift), valores consecutivos del parámetro pueden describirse mediante la función:

$$
k_{t}=k_{t-1}+c_{t}+e_{t}
$$

donde $c$ representa una constante que modifica el valor de $k$ para cada instante t. El valor de $c$ lo podemos estimar como:

$$
c=\frac{1}{T-1}\left(k_{T}-k_{1}\right),
$$

siendo $T$ el valor del último periodo de observación.

La fórmula para la estimación de la tasa central de mortalidad futura en el momento $T+\Delta t$ sería entonces:

$\widehat{m}_{x, T+\Delta t}=e^{a_{x}+b_{x} k_{T+\Delta t}}=e^{\bar{m}_{x}+b_{x}\left(k_{T}+\Delta t \cdot c\right)}$

El modelo de Lee-Carter se puede entender como un modelo de Componentes Principales (Lee y Carter, 1992; Girosi y King, 2007) que está compuesto por una sola componente $\left(b_{x} k_{t}\right)$ y que es suficiente para describir la mayor parte de la varianza del sistema.

Consideramos una matriz de $P$ x $T$ elementos compuesta por logaritmos naturales de la tasa central de mortalidad $\ln \left(m_{x, t}\right)$ para varias edades $x \in P$ y en varios instantes $t \in T$. Asumimos que el espacio $P$ dimensional puede ser reducido hasta una sola dimensión sin mayor pérdida de información. Un modelo compuesto por $P$ componentes sería: of the United States, found out that for their studied set of data values of $k_{t}$ follow the pattern of a single walk with drift. Other populations and sets of data may, however, require the use of other methods of time series (Lee and Carter, 1992).

If $k_{t}$ follows the single walk with drift pattern, then consecutives values of the parameter can be described with the formula:

$$
k_{t}=k_{t-1}+c_{t}+e_{t}
$$

where the constant $c$ represents the change in $k$ in each period $t$. The value of $c$ can be calculated as:

$$
c=\frac{1}{T-1}\left(k_{T}-k_{1}\right),
$$

where $T$ is the value of the last observation.

Future mortality at the moment $T+\Delta t$ can be described with the following equation:

$\widehat{m}_{x, T+\Delta t}=e^{a_{x}+b_{x} k_{T+\Delta t}}=e^{\bar{m}_{x}+b_{x}\left(k_{T}+\Delta t \cdot c\right)}$

The basic Lee-Carter model can also be defined as a Principal Component Analysis model (Lee and Carter, 1992; Girosi and King, 2007), composed of only one component $\left(b_{x} k_{t}\right)$ which is sufficient to describe the majority of the system variability.

We consider a matrix of $P$ x $T$ elements composed of natural logarithms of central death rate $\ln \left(m_{x, t}\right)$ for various ages $x \in P$ and observation periods $t \in T$. We assume that the $P$-dimensional space can be reduced to only one dimension without major loss of information. The model composed of $P$ components is: 


$$
\begin{gathered}
\ln \left(m_{x, t}\right)=a_{x}+b_{x 1} k_{t 1}+b_{x 2} k_{t 2}+\cdots \\
+b_{x A} k_{t P}
\end{gathered}
$$

Si el modelo anterior lo reducimos a una sola componente, se obtiene el modelo presentado por Lee y Carter. La única componente es una función lineal del tiempo.

$$
\begin{gathered}
\ln \left(m_{x, t}\right)=a_{x}+b_{x 1} k_{t 1}+b_{x 2} k_{t 2}+\cdots \\
+b_{x A} k_{t P}
\end{gathered}
$$

If the model above is reduced to only one component, we obtain the model proposed by Lee and Carter. The unique component is a lineal function of time:

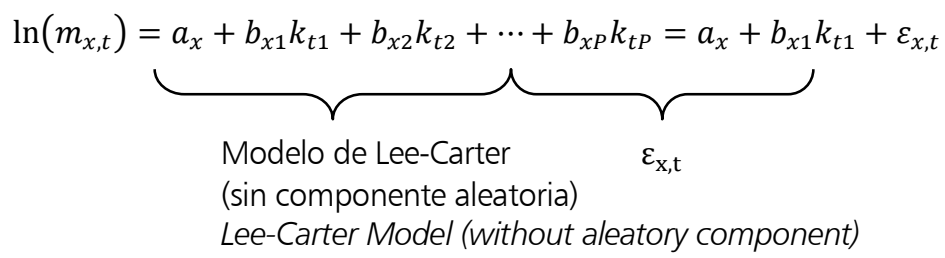

La aplicación del método de Análisis de Componentes Principales a la población de España (Dylewska y Galindo, 2011) demuestra que para una población entre 40 y 85 años y para los años 1958-2009, un modelo compuesto por una componente principal describe alrededor de un $95 \%$ de la varianza del sistema. Por lo tanto, la aplicación del modelo de LeeCarter en su forma básica para pronosticar la mortalidad de hombres y mujeres de España se considera adecuada.

Entre otros estudios donde se comprueba la adecuación del modelo de Lee-Carter a los datos destaca el estudio realizado por Girosi y King (2007) para datos históricos sobre la mortalidad en Estados Unidos y varios países europeos. Los autores analizan una matriz de datos que consiste en la mortalidad por grupos de edad, tiempo y causas de muerte. Los resultados obtenidos indican que en el caso del análisis de la mortalidad en EEUU sin distinción de causa de muerte, el modelo compuesto por una componente explica un $93 \%$ de la variabilidad. También realizan el análisis para España, obteniendo un porcentaje de varianza explicada por la primera componente igual al 89\%.
Application of Principal Component Analysis to the population of Spain (Dylewska and Galindo, 2011) shows that for a population ranging 40-85 and in years 1958-2009, the Lee-Carter model composed of only one component describes the great majority of the system variability (around 95\%). Therefore, the use of the basic Lee-Carter model for projecting future mortality evolution can be considered as adequate.

Beyond other studies that verify the LeeCarter model adequacy to describe mortality evolution, there is a study conducted by Girosi and King (2007) for historical data regarding the mortality in the United States and various European countries. The authors analyze a matrix of data regarding mortality in various age groups, years and causes of death. The results imply that in the case of the United States and for total deaths (without considering cause of death), the model composed of only one component describes $93 \%$ of the total variability. In the case of Spain, the percentage of variability described by the model with one component is $89 \%$. 


\section{PARÁMETROS DEL MODELO DE LEE- CARTER}

El modelo de Lee-Carter fue ajustado a las tablas de mortalidad anuales de España para los años 1985-2009 (25 años consecutivos) publicadas por HMD (Human Mortality Database). La razón del uso de esta base de datos en lugar de las tablas de vida oficiales (INE) es que el HMD proporciona una metodología de construcción de las tablas de vida uniforme para todos los países (Wilmoth et al., 2007).

Una buena aproximación sobre los cambios de mortalidad en la población española lo proporcionan las representaciones gráficas de los coeficientes $a_{x}, b_{x}$ y $k_{\mathrm{t}}$ obtenidos:

\section{- Coeficiente $a_{x}$ :}

La observación de los valores del coeficiente $a_{x}$ permite confirmar cómo crece con la edad el valor medio del riesgo de mortalidad. Destaca un mayor riesgo de mortalidad de hombres frente al riesgo de mortalidad de mujeres y el incremento de mortalidad de jóvenes alrededor de la edad de 20 años. Este incremento es más fuerte en el caso de hombres que en el de mujeres y es la consecuencia del aumento del número de accidentes entre jóvenes.

\section{PARAMETERS OF LEE-CARTER MODEL}

The Lee-Carter model presented in this study has been adjusted to annual mortality tables of Spain for the years 1985-2009 (25 consecutive years) published by HMD (Human Mortality Database). The reason to use this database rather than the Spanish Statistics Institute (INE) tables is that the study was also conducted for other countries and HMD applies a uniform methodology of study for all populations (Wilmoth et al., 2007).

Graphical representations of estimated coefficients $a_{x}, b_{x}$ and $k_{t}$ are also very helpful in observing changes of mortality over the period under study:

- Coefficient $a_{x}$ :

The observation of values of the coefficient $a_{x}$ helps to understand how much increase in age affects the average value of mortality risk. On the graph below it can be observed how much risk of male death is higher than in the case of females, as well as the increase in mortality risk in a younger group - around an age of 20 year-olds. This increase of risk is higher for males than for females and it is a consequence of accidental deaths.

\section{Gráfico 1 Coeficiente ax del modelo de LC para la población de España Graph 1. Coefficienta $a_{x}$ of the model of Lee-Carterfor population of Spain}

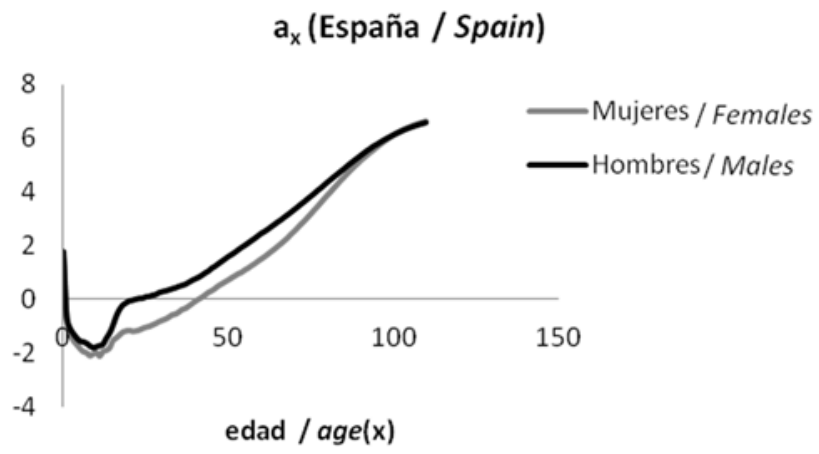


Coeficiente $b_{x}$ :

El coeficiente $b_{x}$ se puede entender como la parte de cambio en el valor medio $\left(a_{x}\right)$ que podemos atribuir al cambio de edad. Este coeficiente modifica la tendencia de $a_{x}$ dependiendo de si el cambio de mortalidad es más rápido o más lento que en el caso de la tendencia $\left(a_{x}\right)$ (Bowers et al., 1997). La evolución de $b_{x}$ también da una idea de lo rápidamente que decrecen los ratios en respuesta a cambios de $k_{t}$ (Dylewska y Galindo, 2011). Destaca un incremento de la mortalidad entre 20 y 30 años de edad.
Coefficient $b_{x}$ :

Coefficient $b_{x}$ can be defined as the part of change in the average value $\left(a_{x}\right)$ that can be assigned to a change in age. Coefficient $b_{x}$ adjusts values of $a_{x}$ depending if the change in mortality is faster or slower than the change in the average mortality $\left(a_{x}\right)$ (Bowers et al., 1997). The observation of the evolution of $b_{x}$ allows us to define how fast the coefficient decreases in relation to the changes in $k_{t}$ (Dylewska and Galindo, 2011). The graph below confirms the previous observation regarding the increase in mortality between 20 and 30 year-olds.

\section{Gráfico 2. Coefic iente $b_{x}$ del modelo de LC para la población de España Graph 2. Coeffic ient $b_{x}$ of the model of Lee-Carter for population of Spain}

\section{$b_{x}$ (España / Spain)}

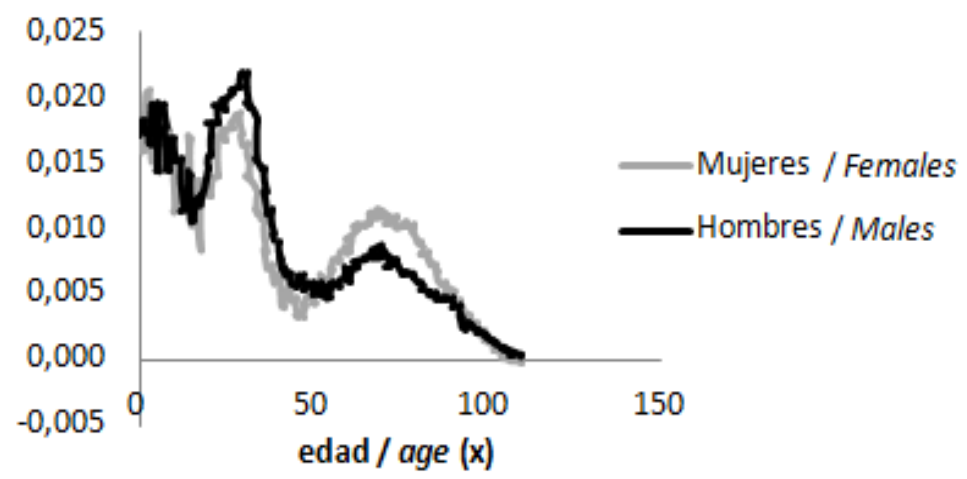

\section{Coeficiente $k_{t}$ :}

Los valores de $k_{t}$ representan la tendencia de la mortalidad a lo largo del periodo de observación. Observando los valores de los coeficientes para hombres y mujeres, podemos decir que la mortalidad tiene tendencia decreciente. Las líneas para los dos sexos son casi iguales.
Coefficient $k_{t}$ :

Values of the coefficient $k_{t}$ represent the overall evolution of mortality over the period under study. The observation of values of this coefficient for males and females makes us come to the conclusion that the tendency is decreasing and that the lines for both sexes are very similar. 
La observación de los valores de $k_{t}$ tiene también otro propósito que es confirmar si los futuros valores de $k_{t}$ se pueden estimar como un camino aleatorio (random walk with drift). Si no es así, habría que buscar otro modelo para la estimación de futuros valores de $k_{t}$. En este caso las representaciones de la función de $k_{t}$ para el momento $t$ tienen una forma decreciente que podría ajustarse a una función lineal. Por lo tanto, se concluye que los futuros valores de $k_{t}$ pueden ser estimados con la función $k_{t}=$ $k_{t-1}+c_{t}+e_{t}$.
Moreover, the observation of values of $k_{t}$ allows us to confirm that future values of $k_{t}$ can be estimated as a random walk with drift. Otherwise, other model for estimation of future values of $k_{t}$ should be adjusted. In this case, the function $k_{t}$ in time $t$ is decreasing and can be described by a lineal function. Therefore, we can conclude that future values of $k_{t}$ can be defined by the function $k_{t}=$ $k_{t-1}+c_{t}+e_{t}$.

\section{Gráfico 3. Coeficiente $k_{t}$ del modelo de LC para la población de España Graph 3. Coefficient kt of Lee-Carter model for population of Spain}

$\mathrm{k}_{\mathrm{t}}$ (España / Spain)

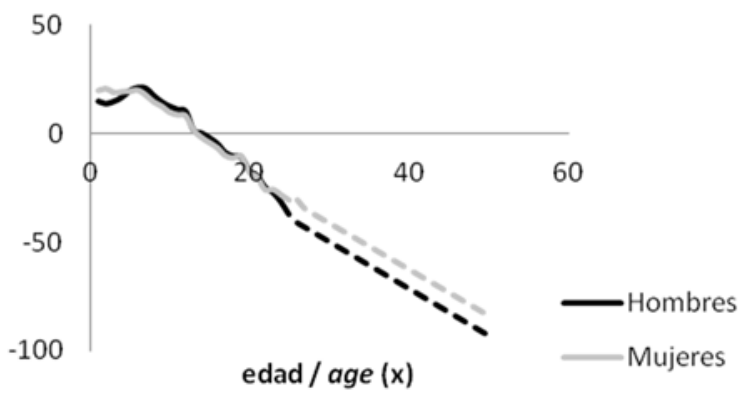

\section{ESPERANZA DE VIDA A LA EDAD $X$ SEGÚN LAS TABLAS ESTÁTICAS Y DINÁMICAS}

Los valores de la esperanza de vida a la edad 0 pronosticados para la población de España para el año 2029 según las tablas de vida estáticas son 81,5 años de vida en el caso de los hombres y 87,2 años de vida en el caso de las mujeres. Esto supone un aumento de 3 años respecto a la esperanza de vida de los hombres en España en el año 2009 y 2,6 años respecto a la esperanza de vida de mujeres en el mismo año. La esperanza de vida a la edad 0 pronosticada según las tablas de vida dinámicas para un individuo nacido en el año 2009 es de 87,2 años en el caso de un hombre y de 92,3 años para una mujer.

\section{REMAINING LIFE EXPECTANCY AT AGE $X$ BASED ON STATIC AND DYNAMIC LIFE TABLES}

Life expectancy at age 0 projected for the population of Spain in the year 2029 and calculated on a basis of static life tables is 81.5 years in the case of males and 87.2 years in the case of females. This implies an increase of 3 years in the expected life-time of males in Spain in year 2009 and a 2.6-year increase in the expected lifetime of females in the same year. Remaining life expectancy at age 0 projected with the use of dynamic life tables for an individual born in 2009 is 87.2 years in the case of males and 92.3 years in the case of females. 
La razón de la diferencia entre la esperanza de vida calculada según las tablas estáticas y dinámicas resulta del distinto método de predicción. Mientras que las tablas estáticas pronosticadas proporcionan solamente un movimiento del riesgo de mortalidad a la edad $x$ en el año $s$ hasta el riesgo de mortalidad a la misma edad en el año $s+t$, las tablas de vida dinámicas permiten el cálculo del riesgo de mortalidad ajustado año por año según transcurre el tiempo y aumenta la edad del individuo. Por lo tanto, las tablas de vida dinámicas permiten el cálculo del valor de la esperanza de vida más adecuado que las tablas de vida estáticas (bien pronosticadas o actuales).
The reason of the difference in life expectancy calculated on the basis of static and dynamic life tables is the different projection method. Static projected life tables assume that the mortality risk in year $s$ at each age $x$ moves into different mortality risk for the same age in year $s+t$. In contrast, dynamic life tables allow us to calculate the mortality risk adjusted year by year, as time passes and population get older. Therefore, dynamic life tables allow for more precise calculation of life expectancy in comparison with static life tables (both projected and actual).

Tabla 3. Esperanza de vida futura en España de un individuo de edad 0 en los años 1989, 2009, 2029 / Table 3. Remaining life expectancy in Spain of an individual of age 0 in years 1989, 2009, 2029

\begin{tabular}{|l|c|c|c|c|c|c|}
\hline \multirow{2}{*}{} & \multicolumn{6}{|c|}{ e $_{0}$ España / Spain } \\
\cline { 2 - 7 } & \multicolumn{3}{|c|}{ Mujeres / Females } & \multicolumn{3}{c|}{ Hombres / Males } \\
\cline { 2 - 7 } & 1989 & 2009 & 2029 & 1989 & 2009 & 2029 \\
\hline $\begin{array}{l}\text { Tablas de vida estáticas } \\
\text { Static life tables }\end{array}$ & 78,5 & 84,6 & 87,2 & 73,4 & 78,5 & 81,5 \\
\hline $\begin{array}{l}\text { Tablas de vida dinámicas } \\
\text { Dynamic life tables }\end{array}$ & - & 92,3 & 94,0 & - & 87,2 & 89,4 \\
\hline
\end{tabular}

Tabla 4. Esperanza de vida futura en España de un individuo de edad 67 en los años 1989, 2009, 2029 / Table 4. Remaining life expectancy in Spain of an individual of age 67 in years 1989, 2009, 2029

\begin{tabular}{|l|c|c|c|c|c|c|}
\hline \multirow{2}{*}{} & \multicolumn{6}{|c|}{ e67 España / Spain } \\
\cline { 2 - 7 } & \multicolumn{3}{|c|}{ Mujeres / Females } & \multicolumn{3}{c|}{ Hombres / Males } \\
\cline { 2 - 7 } & 1989 & 2009 & 2029 & 1989 & 2009 & 2029 \\
\hline $\begin{array}{l}\text { Tablas de vida estáticas } \\
\text { Static life tables }\end{array}$ & 17,5 & 20,2 & 22,1 & 14,1 & 16,6 & 18,4 \\
\hline $\begin{array}{l}\text { Tablas de vida dinámicas } \\
\text { Dynamic life tables }\end{array}$ & - & 21,5 & 23,4 & - & 17,6 & 19,4 \\
\hline
\end{tabular}


Un aspecto adicional es la necesidad de creación de las tablas de vida unisex como consecuencia de la implementación de la Directiva de la Unión Europea 2004/113/ WE. No cabe duda que tanto el nivel de mortalidad como la tendencia de disminución de la mortalidad son muy distintos para hombres y mujeres. La aplicación de las tablas de vida dinámicas en la construcción de tablas unisex permite proteger un producto de seguros ante el riesgo de longevidad y de cambio de estructura de sexo resultante del distinto riesgo de mortalidad para hombres y mujeres.

Las tablas de vida dinámicas unisex las podemos construir utilizando dos modelos de Lee-Carter, estimados por separado para la población de hombres y mujeres, obteniendo los valores de $m_{x}$ y $q_{x}$ pronosticados. Sumando los parámetros $d_{x}$ y $l_{x}$ para los dos sexos podemos asumir previamente una proporción de cada sexo, que refleja la estructura en el momento de entrada al grupo de asegurados (el momento de adquisición). Una gran ventaja de este método de creación de las tablas de vida unisex consiste en el hecho de que las tablas reflejan no solamente el cambio de mortalidad resultante del incremento de edad y tiempo, sino también cambios de estructura de sexo en un grupo de asegurados. Esto se refiere sobre todo al incremento de la proporción de mujeres en el grupo debido al menor riesgo de mortalidad que presentan.

\section{CONCLUSIONES}

La construcción del modelo de Lee-Carter ha permitido realizar un pronóstico de la mortalidad futura en España para los próximos 20 años. Dado el alto porcentaje de variabilidad explicada por el modelo en su forma básica (con una sola componente), el modelo tiene una alta probabilidad de pronosticar bien el nivel de morta-
Another aspect to bear in mind is the need of constructing unisex mortality tables as a consequence of the implementation of the European Union Directive 2004/113/WE. Without doubt both risk of mortality and mortality improvement of males and females are very different, which makes the issue of unisex product pricing even more complex. The application of dynamic life tables in constructing unisex life tables allows for better fit of the model and mitigates the longevity risk and risk of change of sex structure resulting from different mortality risk of males and females.

Unisex mortality tables can be constructed by using two Lee-Carter models estimated separately for populations of males and females, obtaining projected values of $m_{x}$ and $q_{x}$. By adding up parameters $d_{x}$ and $l_{x}$ for both sexes, we can make an assumption about the proportion of each sex which reflects the gender structure at the contract issue date. The main advantage of this approach is that unisex life tables constructed with this method reflect changes of mortality in portfolio which result not only from an increase in age but also the mortality improvement and the change in insured's gender structure in portfolio. This especially relates to the increase in the proportion of females over years due to their lower mortality risk.

\section{CONCLUSIONS}

As a result of the estimation of the LeeCarter model for the population of Spain, a prognosis of the future mortality for next 20 years has been made. Taking into account that the proportion of mortality explained by the first component of this model is very high, the chances for good projection using the basic formula of the model are very high. Values of the parameters of the Lee-Carter model, despite 
lidad futura. Sin embargo, los valores de los parámetros del modelo de Lee-Carter calculados en este estudio, aunque permiten una estimación a largo plazo, deberían ser verificados periódicamente ya que los valores del parámetro $b_{x}$ no suelen ser constantes a lo largo de periodo de observación y vienen afectados por el horizonte temporal elegido. Además, el parámetro $a_{x}$, siendo una media aritmética, depende fuertemente del periodo elegido para la estimación del modelo.

El cálculo de la esperanza de vida a la edad 0 (eo) para tablas estáticas y dinámicas, difiere considerablemente cuando se trabaja con cada tipo de tabla, hecho esperable ya que las tablas dinámicas consideran el continuo decrecimiento del riesgo de mortalidad. La esperanza de vida de un individuo-hombre que nacerá en España en el año 2029 según las tablas estáticas (tradicionales) es de 81,5 años mientras que la esperanza de vida calculada con las tablas de vida dinámicas alcanza el valor de 89,4 años. La previsión de vida de las españolas es de 87,2 años para tablas estáticas y 94,0 años para las tablas dinámicas. allowing for a long term prognosis, should be periodically verified as values of the coefficient $b_{x}$ are likely to change over the period under study. Moreover, the parameter $a_{x}$ is the arithmetic average of the mortality risk and it is strongly affected by the selected period in question.

Remaining life expectancy at age $0\left(e_{0}\right)$ calculated with the use of static and dynamic life tables differs a lot, which results from continuous mortality improvement assumed for dynamic life tables. The life expectancy for a male who will be born in Spain in year 2029 according to static (traditional) projected life tables is 81.5 years while life expectancy calculated using dynamic mortality tables is 89.4 years. The relevant figures for females are 87.2 years of life according to static projected life tables and 94 years for dynamic life tables.

\section{BIBLIOGRAFÍA / REFERENCES}

Booth, H. (2006). Demographic forecasting: 1980 to 2005 in review. International Journal of Forecasting, 22(3), 547-581.

Bowers, N.L., Gerber, H.U., Hickman, J.C., Jones, D.A. y Nesbitt, C.J. (1997). Actuarial mathematics (2nd ed.). Schaumburg (Illinois): Society of Actuaries.

Continuous Mortality Investigation (CMI) Committee (2007). Stochastic projection methodologies: Lee-Carter model features, example results and implications. CMI Working Paper No. 25.

Continuous Mortality Investigation (CMI) Committee (1999). Standard tables of mortality based on the 1991-1994 experiences. The distribution of policies per life assured. CMI Report No. 17.

Debón Aucejo, A., Martínez Ruiz, F. y Montes Suay, F. (2006). Dynamic life tables. Age-periodcohort models. Paper presented on the $10^{\text {th }}$ International Congress on Insurance: Mathematics and Economics (IME). Leuven (Bélgica), $18^{\text {th }}$-20th July. 
Debón Aucejo, A., Martínez Ruiz, F. y Montes Suay, F. (2007). Modelo Lee-Carter extendido. XV Jornadas de ASEPUMA y III Encuentro Internacional. Palma de Mallorca, 20-21 de septiembre.

Dylewska, E. y Galindo Villardón, M.P. (2011). Aplicación del modelo de Lee-Carter para la construcción de tablas de mortalidad dinámicas para Polonia y España. Universidad de Salamanca: Trabajo Fin de Máster no publicado.

Girosi, F. y King, G. (2007). Understanding the Lee-Carter Mortality forecasting method. Copy at http://gking.harvard.edu/files/lc.pdf.

Lee, R.D. y Carter, L.R. (1992). Modelling and forecasting U.S. mortality. Journal of the American Statistical Association, 87(419), 659-671.

López Cachero, M. y López de la Manzanara Barbero, J. (1996). Estadística para actuarios. Madrid: MAPFRE.

Rossa A. (2009). Dynamiczne tablice trwania życia oparte na metodologii Lee-Cartera i ich zastosowanie do obliczania wysokości świadczeń emerytalnych. Acta Universitatis Lodziensis. Folia Oeconomica, 231, 367-384.

Wilmoth, J.R., Andreev, K., Jdanov, D. y Glei, D.A. (2007). Methods protocol for the human mortality database. Version 5. [http://www.mortality.org/Public/Docs/MethodsProtocol.pdf]. 